Journal of Agricultural Science in Finland Maataloustieteellinen Aikakauskirja

Vol 63:255-85

\title{
COMPETITION AND YIELD ADVANTAGE IN BARLEY-BARLEY AND BARLEY-OATS MIXTURES
}

Selostus: Kilpailu ja satoetu sekä ohran lajikeseoksissa että ohran ja kauran lajiseoksissa

\section{KARI JOKINEN}

Department of Crop Husbandry,

University of Helsinki

SF-00710 Helsinki, Finland

ACADEMIC Dissertation

TO BE PRESENTED, WITH THE PERMISSION OF THE

FACUlTy OF Agriculture AND Forestry OF THE

UNIVERSITY OF HELSINKI, FOR PUBLIC CRITICISM

in Auditorium XiI, Aleksanterinkatu 5, Helsinki,

ON NOVEMBER 8th 1991, AT 12 O'ClOCK NOON.

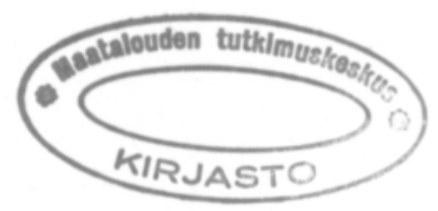




\section{ACKNOWLEDGEMENTS}

This work was carried out at the Department of Crop Husbandry, University of Helsinki.

I wish to express my sincere gratitude to Professor emeritus Eero Varis, who proposed the subject for my dissertation and for his support at all stages of the work.

I am very grateful to Docent Eija Pehu and Professor Erkki Kaukovirta, the referees of this work for invaluable advice and criticism in finalizing this thesis.

My sincere thanks are due also to my colleagues, especially to Docent Juha Helenius, Docent Reijo Karjalainen, Mr. Markku Yli-Halla, M.Sci., Docent Timo Törmälä and Docent Pauli Seppänen for discussions and their interest shown during the work.

I wish to thank Docent Leila-Riitta Erviö and Professor Peter M.A. Tigerstedt for the stimulating discussions.

I am indebted to Mrs. Aira Vainiola for the protein analyses and to Mr. Reino Hakala and Mr. Jouko Närhi for their technical assistance in the field experiments in Viikki.

I want to express my very special thanks to the staff of the Finnish Seed Testing Station for their excellent assistance in identification of barley varieties from the seed yield.

I also want to express my special thanks to the technical staff on the Kotkaniemi Experimental Farm of Kemira Oy for their cooperation in carrying out part of the field experiments.

My warm thanks are due to Mr. Tuomo Perälä, M.Sci., for his contribution to this work.

My warm thanks are due to Mrs. Sevastiana Ruusamo, M.A., Dr. David Thompson and Mr. Peter Joy, M.Sci., for linguistic revision of the manuscript.

I am very grateful to all those persons, too numerous to name here, who have helped me during recent years.

This study was initially supported by the University of Helsinki. Financial support from the Academy of Finland, Kemira Oy and the Scientific Foundation of the Finnish Association of Academic Agronomist (Raisa and S.G. Nieminen's Special Fund) is gratefully acknowledged.

I am grateful to the Scientific Agricultural Society of Finland for including this study in their series of publications.

Finally, I express my warmest thanks to my wife Eeva-Maija and to our son Olli for their encouragement, understanding and patience during my work. I wish to express my special gratitude to my parents for their support during these years. 



\section{Competition and yield advantage in barley-barley and barley-oats mixtures}

\section{Contents}

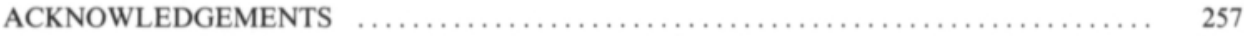

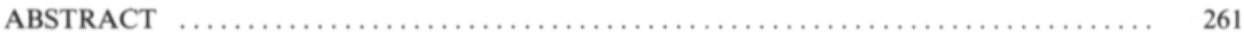

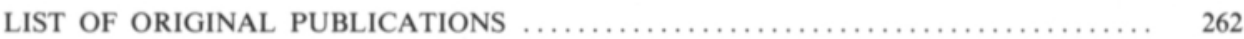

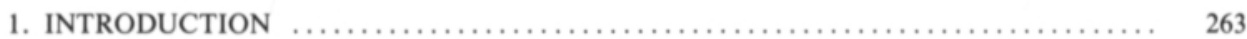

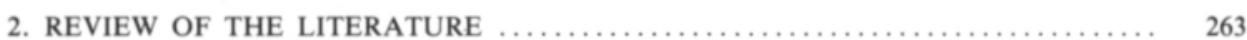

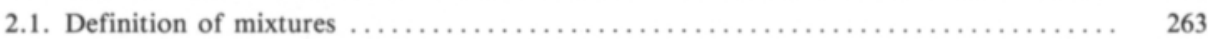

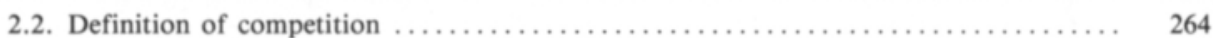

2.3. Characterization of yield advantage from mixed cropping $\ldots \ldots \ldots \ldots \ldots \ldots \ldots \ldots 265$

2.4. Experimental designs used in studies on competition and their applicability to mixed

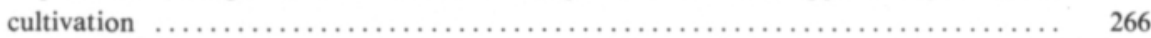

2.5. Occurrence of yield advantage in barley-barley and barley-oats mixtures ......... 268

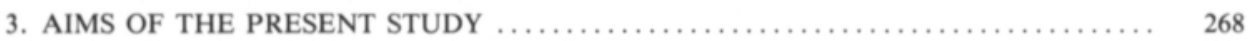

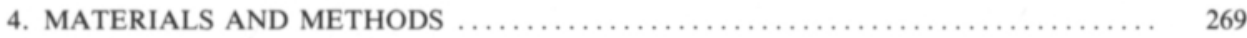

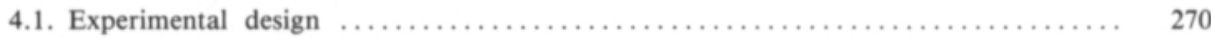

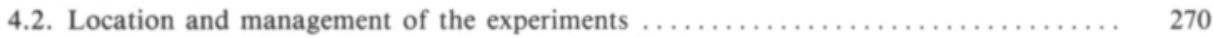

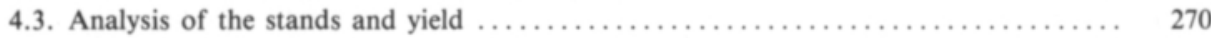

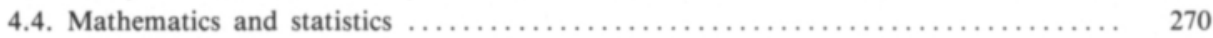

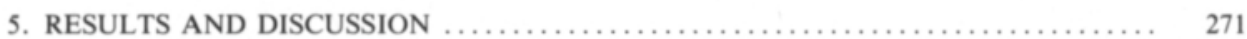

5.1. Applicability of the linear regression model to studies on the competition and grain

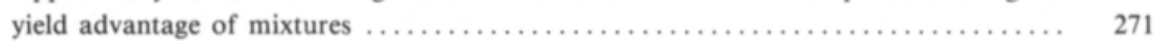

5.2. Competitive hierarchies in mixtures and the stability of competitive relations ...... 273

5.3. Factors affecting competition between components and competitive ability of a genotype 274

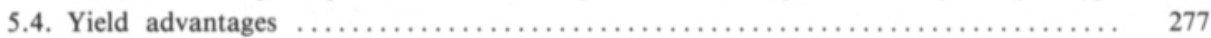

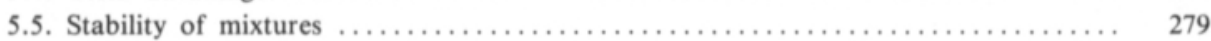

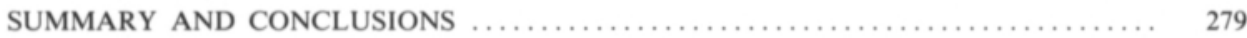

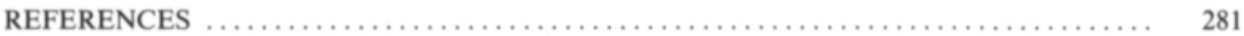

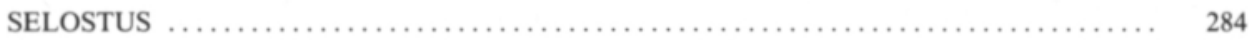





\title{
Competition and yield advantage in barley-barley and barley-oats mixtures
}

\author{
KARI JOKINEN \\ Department of Crop Husbandry, University of Helsinki \\ SF-00710 Helsinki, Finland
}

\begin{abstract}
Competition and yield advantage in barley varietal mixtures and in barley-oats mixtures were investigated. The trials were based on replacement series, but in a few cases the overall density of the stand was varied on the basis of an addition series.

Both models of competition, one based on the de Wit model and the other upon a linear regression model, agreed as to which component was the dominant and which was the subordinate in the mixture. The competition coefficients from regression analyses depicted competition between components better in a dense than in a sparse stand.

The competitive ability of a genotype did not depend directly upon individual characters of the genotype, such as rate of initial development, earliness, culm height, tillering capacity or grain yield in monoculture (adaptation). A good combination of characters from the viewpoint of competition was provided by the barley cv. Arra with its rapid initial development and rapid culm growth (earliness), the variety being dominant irrespective of number of components in the mixture, stand density, level of nitrogen fertilization or growing season. This suggests that competitive relations and distribution of resources within a mixture are determined at an early stage in the growing period. In other cases the competitive ability of a genotype varied from one environment to another with the competitive relations between components being inconsistent. The dominance of an aggressor usually increased with increasing nitrogen fertilization especially when the total density of the stand was high. As a rule, competition affected all the components of yield with the kernel weight being least affected.

The grain yield of varietal mixtures did not differ from the yield of the highest yielding component grown alone, i.e. mixtures did not overyield. The relative yield total of varietal mixtures was higher at low $(\mathrm{RYT}>1)$ than at optimal densities $(\mathrm{RYT}=1)$. Also the relative yield total was higher under conditions where the nitrogen fertilization was not optimal. The results of a varietal trial repeated during three successive years indicated that the relative yield total of a given mixture varied from one growing season to another, fluctuating around unity. Thus highly adapted barley varieties appear to compete for the same resources, and the grain yield advantage of such mixtures is marginal.

The results of the barley-oats mixture trials revealed that the mixture may overyield. The relative yield totals of barley-oats mixtures were usually equal to or greater than unity the latter suggesting that the mixtures of barley and oats may use resources more efficiently than monocultures, and some grain yield advantage could be achieved with such mixtures.

The protein yield of the barley-oats mixtures did not differ from the yield of the highest yielding component grown alone. The ratio of actual and expected protein yield and the relative protein yield total were usually slightly greater than one. The grain yields of mixtures were not consistently more stable than monocultures as determined by the coefficient of variation.
\end{abstract}

Index words: Competition, yield advantage, barley, oats, mixtures, models 


\section{List of original publications}

This thesis is based on the following publications, which in the text will be referred to by their Roman numerals:

I. JOKINEN, K. 1991. Yield and competition in barley variety mixtures. J. Agric. Sci. Finl. 63: 287-305.

II. JOKINEN, K. 1991. Assessment of competition and yield advantage in addition series of barley variety mixtures. J. Agric. Sci. Finl. 63: 307-20.

III. JOKINEN, K. 1991. Competition and yield performance in mixtures of oats and barley - nitrogen fertilization, density and proportion of the components. J. Agric. Sci. Finl. 63: 321-40.

IV. JOKINEN, K. 1991. Influence of different barley varieties on competition and yield performance in barley-oats mixtures at two levels of nitrogen fertilization. J. Agric. Sci. Finl. 63: 341-51.

V. JOKINEN, K. 1991. The effect of site on competition and yield advantages of mixture of barley and oats. J. Agric. Sci. Finl. 63: 353-59. 


\section{INTRODUCTION}

Mixed cropping has been general practice throughout the tropics and subtropics since time immemorial. In the main, the choice of mixed cropping has been, and still is founded upon an assumed advantage over monocultures that is based upon experience rather than upon accepted scientific procedures. Interest in mixed cropping has grown in recent years. The reason for the revived interest is that mixed cropping is regarded as a potentially superior, even a more efficient method of crop production than methods based on only a single crop species or variety (e.g. HARPER 1977, Trenbath 1974, 1976, 1983, Wolfe 1985, VANDERMEer 1989). The advantages arising from the use of mixtures may often be exploited by simply mixing certain genotypes together without the need for any additional inputs.

The systematic investigation of mixed cropping is still a new field, and no traditions of research have yet developed. This is apparent from the wide variety of different concepts of research priorities, and especially of approaches adopted within the field by different workers. The difficulties in analyzing the results of mixture trials are reflected in the diverse and often divergent ways of interpreting trial results and of assessing the advantage of mixtures over sole crops (e.g. Pearce and Gilliver 1978, Trenbath 1978, Willey 1979, 1985, Mead and Riley 1981, Gilliver and Pearce 1983, Pearce and Edmondson 1984, VANDERMEeR 1989). Scientists are gradually becoming aware that if their research into yield formation and the factors determining it is restricted to monocultures their insight into yield formation in mixtures and the possibilities of exploiting mixture effects will remain partial, even biased.

There are three aims of research on mixed cropping (Trenbath 1974). The first aim is to screen from mixtures constituted more or less at random the combinations which are most productive and best suited to a given area of cultivation. The second task is to study and test under standard conditions traditionally grown mixtures which have been claimed to perform well. The third aim, which is probably the most important from the standpoint of promoting research into crop mixtures, is to understand the chemical, physical and biological phenomena underlying the possible advantage of mixtures over the corresponding sole crops. Of these factors, interplant competition for resources is one of the most influential in determining the magnitude of the yield advantage of a mixture. This third aim is by far the most challenging and complex.

The main object of the present study was to compare the yielding abilities of barley varietal mixtures and of barley-oats interspecific mixtures with the respective pure stand yields, and to examine the nature of competition between the components.

\section{REVIEW OF THE LITERATURE}

\subsection{Definition of mixtures}

Mixtures used in crop production may be interspecific or intraspecific. There are several alternatives to increase the heterogeneity of a crop stand by the use of intraspecific mixtures (Wolfe 1985). The various modes of heterogeneity actually form a continuous series represented by multilines at the one extreme and by varietal mixtures at the other.

In the multiline mixtures the components differ from each other only with respect to certain identifiable genes, e.g. disease resistance factors. According to Wolfe and BarRetT (1979) and WolfE (1985), varietal mixtures offer the best possibilities of exploiting intraspecific mixture effects in practical farming. A particular feature favouring the use of varietal mixtures over other intraspecific mixtures is that the former are considerably easier to prepare than, for instance, multilines. Varietal mixtures also possess a greater genetic capacity to withstand most abiotic and biotic stresses than multiline mixtures. A disadvantage of varietal mixtures as compared with other intraspecific mixtures could be the likelihood of the mixture's greater heterogeneity with respect to quality of the yield. 


\subsection{Definition of competition}

According to BEGON et al. (1986 p.203) competition can be defined as an interaction between individuals brought about by a shared requirement for a resource in limited supply and leading to a reduction in the survivorship, growth, and/or reproduction of the individuals concerned. The first part of this definition focuses on the causes of competition resources are required by different individuals and are shared out among them. The second part focuses on the effects on population dynamics - the reduction in the contribution made by individuals to future generations when they are brought together (FIRBANK and WATKINSON 1990).

However, different schools of thought define competition in various ways, which testifies for the manifold nature of competition and for the diversity of phenomena underlying it. According to the so-called American school (see e.g. VANDERMEER 1989 p.9), all negative interactions occurring between plant individuals or populations constitute competition. The concept of competition can be divided into exploitative competition involving competition for some resource, i.e. competition for the same growth factor(s). Another type of competition is interference competition, in which individuals or populations interfere with each other's growth e.g. by mutual shading or the production of allelochemicals. Interference can also result from the effects of saprophytic organisms living in the root systems, truly pathogenic organisms and various insects which attack plants.

According to the so-called British school (see e.g. HARPER 1977), the term competition should be used only when plants compete for growth factors. By defining competition in this way, one excludes all other types of direct or indirect modes of interaction between plants, which can be attributed to interference.

More recently the traditional terminology of competition has been elaborated still further, mainly in order to take into account the complex interactions prevailing among differ- ent organisms (Clay 1990, Connell 1990, LoudA et al. 1990). On the basis of the new models, competition can be divided into real competition and apparent competition. Real competition includes direct interference and indirect exploitation of shared resources. Apparent competition is caused by indirect interaction via a shared enemy or indirect interaction via other species. Thus apparent competition is dependent on the presence of additional species other than the competing species in question. The relative contributions of various mechanisms in different competitive situations can be difficult to quantify, especially from field experiments.

According to Fowler (1990), the operation and outcome of competition between individuals of two or more plant genotypes or species may be consistent and predictable, that is, orderly. Alternatively, the outcome of competition between plants may be quite inconsistent and hence unpredictable, that is, disorderly. The more factors upon which the outcome depends, and the larger the stochastic component of the interaction, the more inconsistent and unpredictable will be the outcome of competition. Climate, location and management activities all contribute to competitive hierarchies among agricultural plants by varying resources, environmental conditions and the degree of vegetative suppression.

The best understood mechanism, which influences the growth of plants irrespective of whether they grow in mixtures or pure stands, is competition for resources (de WIT 1960, Donald 1963, Harper 1977, Trenbath 1974, 1976, Tilman 1982, 1988, 1990, VANDERmeER 1989). Plants compete for limited resources which are essential for plant growth and development (light, water, nutrients, oxygen and carbon dioxide). Competition can occur above or below ground, or both (TILMAN 1982, 1988). In general, the growth of a healthy, young plant is dependent upon the rate of absorption of any of the growth limiting factors (Trenbath 1976). Competition is usually most intense for a given resource where that resource is most limiting and competition for 
all resources is most intense where density or biomass is greatest (GolDBERG 1990).

In a young stand, where the leaf area and root density are still at low levels, the availability of growth factors to an individual growing in the stand is as great as for an isolated individual. As the biomass of individuals increases, the distances between stems and roots decrease in the stand, which results in changes in availability of resources. As the stand becomes increasingly dense and neighbour effects intensify, the growth of the individual in the stand slows down relative to the isolated individual (Trenbath 1976, HákansSon 1983, Weiner and Thomas 1986, Firbank and WATKINSON 1985, 1990). It is important to note that the plant's reaction to a neighbouring individual is less a direct effect of the neighbour than the affected plant's response to its own altered microenvironment. According to GoldBerg (1990), such indirect interactions consist of two distinct processes: one or both plants has an effect on abundance of the intermediary and/or response to changes in abundance of the intermediary. Competition for resources involves negative effects (e.g., light depletion under a plant canopy) and positive responses (e.g., the dependence of growth or survival on available light). Thus a plant can be a good competitor in two ways: by rapidly depleting a resource or by being able to continue growth at depleted resource levels.

Competition within mixtures is more complex than in monocultures as physiological and morphological differences between genotypes, for instance in the extent of the stems or roots, will affect competition for resources (Grime 1979, Tilman 1982, 1988). Caldwell and RicharDS (1986) have argued that allocation and architecture are of greater importance than physiological activity rates in determining relative effects on resources among similar-sized plants.

Competition for resources comprises a series of events which result in an uneven distribution of growth factors among plant individuals in the stand. The different ways in which plants react to this uneven distribution of growth factors is the cause of variation in size among individuals (Вцоом et al. 1985), but in extreme cases self-thinning is possible as well (FIRBANK and WATKINSON 1990). Even though there are differences in size among individuals before competition for growth factors begins, competition tends to augment or enhance these differences (SPITTERS 1984, SPITTERS and Kramer 1986), which results in competitive hierachies (KeDdy 1990).

One cannot, by means of field trials, conclusively demonstrate for what growth factors or at what stage of development there has been competition (HARPER 1977, VANDERMEER 1989). It is rather likely that all the growth factors will limit the growth of plants, since the plant responds homeostatically to resource imbalance by allocating new biomass to acquisition of the resources that most strongly limit growth (MOONEY 1972, THORNLEY 1972, Bцоом et. al. 1985).

\subsection{Characterization of yield advantage from mixed cropping}

Characterization of yield advantage from mixed cropping is not necessarily simple. According to WILLEY (1979), the yield advantage from cultivating mixtures may be based on three criteria:

a) The main component of a mixture must produce a full yield and the secondary component (crop) must produce at least some yield.

In this case it is easy to assess whether there is any yield advantage, since by definition there will be a yield advantage whenever the secondary component produces a measurable crop.

b) The mixture must outyield a monocrop of the higher yielding component.

This definitive criterion has been traditionally used in mixture studies involving herbage crops (Donald 1963, van den Berg 1968) and in some other studies as reviewed by TRENBATH (1974). This criterion for defining yield 
advantage is based upon the assumption that a yield unit of any component is of equal value with regard to quality.

c) The yield of the mixture must exceed the combined sole crop yield of the components.

In this situation, a yield advantage occurs if mixtures give higher yields than growing both the component crops separately. This is much the commonest situation in practice, too. It is also the situation in which the magnitude or even the existence of a yield advantage is not readily apparent. Part of the problem is that component crops which are often very different in type, or level of yield must be put on some comparable basis. A more difficult aspect is that any assessment of a yield advantage involves the comparison of a mixture situation in which the component crops are competing with each other, with a sole crop situation in which they are not. Such a comparison must take into account the competitive relationships between the components (see next section).

\subsection{Experimental designs used in studies on competition and their applicability to mixed cultivation}

Replacement series design. Most of the competition studies on crop plants have been made by using replacement series. The design and analysis are popular not least because they are based on small experiments. A replacement series design consists of pure stands of the species and one or more mixtures made by replacing a proportion of one component by a corresponding proportion of the other, holding the overall density constant (de WIT 1960, HarPer 1977, Willey 1979).

De WIT (1960) proposed a model for competition between plants. The model is based upon the assumption that the development of biomass of each component of the mixture corresponds to that component's share of the available growth factors. If the growth factors are unevenly distributed in the mixed stand among the various components, the model will predict that individuals of one of the genotypes, i, will yield more in the mixture than in pure stand, while those of the other genotype, $\mathrm{j}$, will yield less in the mixture than in pure stand. In this type of situation genotype $i$ is the aggressor and $j$ the subordinate. Trenbath (1978) concluded that this proportional model generally gives a superior fit compared to the additive model, indicating that competition for the same resources is very common.

Based on the replacement series experiments three main classes of mechanisms which contribute to competitive relations between components of a mixture was proposed by MEAD and Riley (1981):

a) Mutual inhibition. The yields of both components grown in mixed stand are smaller than expected.

b) Mutual cooperation. The yields of both components grown in mixed stand are larger than expected.

c) Compensation. This is by far the most common situation, in which one component produces a higher yield, the other a lower yield than expected. The components differ in their competitive abilities.

If components of a mixture inhibit one another, no advantage is to be gained from mixed cropping. Conversely, the existence of mutual cooperation between components in a mixture renders a yield advantage possible. In the case of compensation it is not always clear whether there is a yield advantage, as an inference of yield advantage based solely on a comparison of absolute yields can be misleading as shown by WILLEY (1979).

To avoid an ambiguous comparison, one can calculate the relative yield total (RYT) (de WIT and van den BERG 1965). This is equal to the sum of the relative yields (RY) of the components of the mixture, where each component's relative yield is the ratio of its yield in the mixture to its yield in pure stand. Using RY values one can place different genotypes in relative and comparative order irrespective of differences in both magnitude and quality 
of yields in pure stand. In addition, the results can be presented graphically. The relative yield total can thus be used as a criterion for yield advantage. If the RYT of a mixture is unity, there can be no yield advantage, since the same yield of each genotype could have been obtained with monocultures as with a mixture, without changing the total area of land. The area fractions of the monocultures have to be taken corresponding to the relative yields of the species. When RYT $>1$, a larger area of land is needed with monocultures than with a mixture to produce the same combined yield of the component genotypes. Also when significant deviations of RYT from unity occur, some form of annidation may be suspected, although the deviation could also be due to allelopathy, non-linear yield response or pathogen activity (TrenBath 1974, 1976, BRAAKHEKKE 1980).

When the overall density of a series of mixtures is not held constant, one can also calculate values of land equivalent ratio (LER) (TRENBATH 1976). For the estimation of LER values one must use total yields per unit area, otherwise the procedure corresponds to that for working out RYT. It follows that LER = RYT when the overall density is held constant.

One can also calculate indices of competitive relationships, such as relative crowding coefficient (de WIT 1960), coefficient of aggressivity (McGilchrist and Trenbath 1971) and competitive ratio (WILEY and RAO 1980). Of these, the competitive ratio is independent of any possible yield advantage of the mixture (WILLEY and RaO 1980). However, the values of indices may be unstable, being dependent on the experimental design (INOUYE and SChafFer 1981, ConNolly 1986, 1987, HÁKANSSON 1988, 1991). Also their statistical behaviour is difficult to comprehend $\left(\mathrm{V}_{\mathrm{AN}}\right.$ DERMEER 1989).

The replacement series design is valuable for comparing the outcome of competition between two plant genotypes under different plant treatments or growing conditions as concluded by HÁKANSSON (1988 p.65, 1991 p.237). Its use has led to important insights into the nature of niche differentiation (TRENBATH 1974) and differential resource use by plants. For example, BerendSE (1982) demonstrated niche differentiation between species with different rooting depths, and Hall (1974) discovered that the depressing effect of Setaria on Desmodium could be ameliorated by the addition of potassium. Other experiments have shown that pathogens can alter the outcome of competition between species (reviewed by BURDON 1987) as can parasitic plants (GIBSON 1986), herbivores (WHITTAKER 1979) and the presence or absence of mycorrhiza (FITTER 1977). In a slightly different use of the replacement series; Cоттам (1985) showed that the intensity with which herbivores feed on plants may vary according to their proportions in mixtures.

Additive designs. In an additive experiment, the density of one component is held constant while that of the other is varied. This design has been criticized by HARPER (1977 p. 249) on the grounds that total density and proportion vary together, thus confounding the effects of total density and frequency. The additive model has been very little used in studies on mixed cropping.

Addition series. Neither the replacement nor the additive designs attempt to describe the complete range of outcomes of competition between two species. These outcomes form a response surface and the substitutive and additive designs are restricted in that they merely take slices through that surface (FIR. BANK and WATKINSON 1990). A thorough understanding of the competitive interaction between pairs of species can only be achieved by growing them in a complete design which includes a wide range of frequencies and total densities (INOuYE and Schaffer 1981). Thus competition can only be measured in absolute terms from trials in which the overall density of the stands can vary, since "total plant weight may be taken as the measure of competition; namely, the smaller the mean plant weight, the more intense the competition within population is considered to be" (KIRA et al. 1953). One possible experimental approach is 
to replicate a replacement series design at a wide range of densities giving an addition series (SPITTERs 1983).

A way of analyzing competitive relationships between plants from addition series is to use methods involving various types of regression analysis (MATHER and CALIGARI 1981, Wright 1981, HäKANSSON 1983, 1988, SPITTERS 1983, FirbanK and WatKINSON 1985, 1990). These methods produce equations which depict intra- and intergenotypic competition. They can be based on a model according to which the reciprocal of the yield of an individual plant is linearly related to the stand density (WILley and HeATH 1969, CoNNOLLY 1986, 1987). The advantage of the additive linear reciprocal equation compared to other equations describing competition lies in the biological significance of the regression coefficients in the model (WRIGHT 1981, SPITTERS 1983). In addition to defining various competitive relationships between components the regression model has been used to evaluate the usefulness of mixtures (WRIGHT 1981).

The additive linear model can be extended to embrace mixtures with more than two components. In this case, however, the number of observation points needed to calculate the regression will increase considerably, since the number of parameters describing the competitive relationships is equal to the square of the number of components (WRIGHT 1981). In practice, the resolution of these more complex relationships will require very large trials. This is doubtless the main reason why so few studies of this kind have been conducted.

\subsection{Occurrence of yield advantage in barley-barley and barley-oats mixtures}

Growing of variety mixtures, multi-lines or bulk hybrids instead of pure line varieties of barley has been proposed as a means of obtaining higher yields. In most cases the yields of the mixtures have been reported to be about the same as or slightly higher than that of the weighted mean of their components (SIM-
MOnds 1962, Allard and Adams 1969, Clay and Allard 1969, Sandfaer 1970, BlijenBURG and SNEEP 1975, LANG et al. 1975, Eisenberg 1980, Nitzshe and Hesselbach 1983, Aufhammer et al. 1984, BaKer and Briggs 1984, Harrabi et al. 1986, HouMOller et al. 1986, Karjalainen and HiIvoLA 1987, Mcdonald et al. 1988, Aufhammer and STUTZEL 1989).

In several studies of barley-oats mixtures grown for feed, grain yield increases over the mean of the components in monoculture have been observed and even overyielding has occurred (SAlminen 1945, van DobBen 1953, BeBAWI and NAYLOR 1978, TAYLOR 1978, FeJer et al. 1982). In trying to combine the two species so that there was less mutual competition at critical stages, Syme and Bremner (1968) found that mixture yields did not exceed the better component and were usually similar to mid-component.

As in the case of varietal mixtures also in most cases of mixtures of oats and barley the yield of the mixture is compared with the average of the yield of the monocultures. A higher yield of the mixture is interpreted as an argument for mixed cropping. This indicates that the yield advantage of mixtures is not always completely assessed. This is because without calculation of the relative yield total (RYT) the interpretations based on the ratio of actual and expected yields can be misleading especially in cases where compensation occurs (WILlEY 1979). Compensation seems to be the most common situation in mixtures of barley and oats, i.e. the competitive abilities of barley and oats differ (for example SALMINEN 1945, de Wit 1960, Syme and Bremner 1968, FEJER et al. 1982). An analysis of relative yield total performed according to the de Wit model is also in most cases impossible because only the total yield of a mixture is reported.

\section{AIMS OF THE PRESENT STUDY}

The overall object of the present study was to compare the yielding abilities of barley 
varietal mixtures (I and II) and of barley-oats interspecific mixtures ( $\mathrm{III}-\mathrm{V}$ ) with the respective pure stand yields, and to examine the nature of competition between the components. Special emphasis was paid to the following topics:

1) To assess the applicability of a linear regression model to the analysis of intraand interspecific mixtures (II, III).

2) To study the types of competitive relationship between barley varieties of different types (developmental rhythm, morphology, adaptation), the stability of the competitive relationships and the way in which varieties combine with respect to possible yield advantage (I, II).
3) To study the competitive relationships between two species (oats and barley), the stability of their competitive relationships and the way in which these species combine with respect to yield advantage (III-V).

4) To study the manner in which stand density and cropping intensity affect the competitive relations between components and the yield advantage of mixtures $(\mathrm{I}-\mathrm{V})$.

\section{MATERIALS AND METHODS}

Herein will follow the general outline of the experiments (Table 1). Details are described in the original publications $(\mathrm{I}-\mathrm{V})$.

Table 1. General description of the trials reported in original publications (I-V).

\begin{tabular}{|c|c|c|c|c|c|c|}
\hline $\begin{array}{l}\text { Trial } \\
\text { Species } \\
\text { Year }\end{array}$ & $\begin{array}{l}\text { Soil } \\
\text { pH } \\
\text { Type }\end{array}$ & $\begin{array}{l}\text { Cultivars, } \\
2=\text { two-row } \\
6=\text { six-row }\end{array}$ & $\begin{array}{l}\text { Density } \\
\text { plants } / \mathrm{m}^{2}\end{array}$ & $\begin{array}{l}\text { Nitrogen } \\
\mathrm{kg} / \mathrm{ha}\end{array}$ & $\begin{array}{l}\text { Mixtures, } \\
\text { Proportions }\end{array}$ & $\begin{array}{l}\text { Reported } \\
\text { in }\end{array}$ \\
\hline 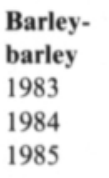 & $\begin{array}{l}5.4- \\
5.8 \\
\text { Muddy clay } \\
\text { Muddy clay } \\
\text { Sandy clay }\end{array}$ & $\begin{array}{l}\text { Agneta (6) } \\
\text { Arra (6) } \\
\text { Hja 673(6) } \\
\text { Pomo (6) }\end{array}$ & 500 & 80 & $\begin{array}{l}\text { Binary, } \\
\text { Tertiary, } \\
\text { Quaternary }\end{array}$ & (I) \\
\hline $\begin{array}{l}\text { Barley- } \\
\text { barley } \\
1984\end{array}$ & $\begin{array}{l}5.5 \\
\text { Sandy clay }\end{array}$ & $\begin{array}{l}\text { Agneta (6) } \\
\text { Pomo (6) } \\
\text { Ida (2) } \\
\text { Kustaa (2) }\end{array}$ & 500 & $\begin{array}{l}50 \\
100\end{array}$ & $\begin{array}{l}\text { Binary, } \\
\text { Tertiary } \\
\text { Quaternary }\end{array}$ & (I) \\
\hline $\begin{array}{l}\text { Barley- } \\
\text { barley } \\
1983\end{array}$ & $\begin{array}{l}4.9 \\
\text { Silty clay }\end{array}$ & $\begin{array}{l}\text { Agneta (6) } \\
\text { Arra (6) } \\
\text { Pomo (6) }\end{array}$ & $\begin{array}{l}200 \\
400 \\
600\end{array}$ & $\begin{array}{l}50 \\
100\end{array}$ & $\begin{array}{l}\text { Binary } \\
\text { Tertiary }\end{array}$ & (II) \\
\hline $\begin{array}{l}\text { Barley- } \\
\text { oats } \\
1983\end{array}$ & $\begin{array}{l}5.6 \\
\text { Muddy clay }\end{array}$ & $\begin{array}{l}\text { Agneta (6) } \\
\text { Veli }\end{array}$ & $\begin{array}{l}200 \\
400 \\
600\end{array}$ & $\begin{array}{l}10 \\
40 \\
80\end{array}$ & $\begin{array}{l}\text { Binary } \\
25 / 75 \\
50 / 50 \\
75 / 25\end{array}$ & (III) \\
\hline $\begin{array}{l}\text { Barley- } \\
\text { oats } \\
1984\end{array}$ & $\begin{array}{l}5.4 \\
\text { Finer } \\
\text { fine sand }\end{array}$ & $\begin{array}{l}\text { Agneta (6) } \\
\text { Veli }\end{array}$ & $\begin{array}{l}200 \\
500 \\
800\end{array}$ & $\begin{array}{l}10 \\
40 \\
80\end{array}$ & $\begin{array}{l}\text { Binary } \\
25 / 75 \\
50 / 50 \\
75 / 25\end{array}$ & (III) \\
\hline $\begin{array}{l}\text { Barley- } \\
\text { oats } \\
1984\end{array}$ & $\begin{array}{l}5.4 \\
\text { Finer } \\
\text { fine sand }\end{array}$ & $\begin{array}{l}\text { Ida (2) } \\
\text { Veli }\end{array}$ & $\begin{array}{l}200 \\
500 \\
800\end{array}$ & $\begin{array}{l}10 \\
40 \\
80\end{array}$ & $\begin{array}{l}\text { Binary } \\
25 / 75 \\
50 / 50 \\
75 / 25\end{array}$ & (III) \\
\hline $\begin{array}{l}\text { Barley- } \\
\text { oats } \\
1986\end{array}$ & $\begin{array}{l}5.2 \\
\text { Finer } \\
\text { fine sand }\end{array}$ & $\begin{array}{l}\text { Aapo (2) } \\
\text { Agneta (6) } \\
\text { Ida (2) } \\
\text { Veli }\end{array}$ & 500 & $\begin{array}{l}80 \\
120\end{array}$ & Binary & (IV) \\
\hline $\begin{array}{l}\text { Barley- } \\
\text { oats } \\
1985\end{array}$ & $\begin{array}{l}5.7 \\
\text { Finer } \\
\text { fine sand }\end{array}$ & $\begin{array}{l}\text { Agneta (6) } \\
\text { Veli }\end{array}$ & 500 & 80 & Binary & (V) \\
\hline
\end{tabular}




\subsection{Experimental design}

The experiments performed in the field were replacement series. In four experiments (II, III) also addition series were included.

The experiments were laid out in a randomized complete block design where only one factor (genotypic composition of the stand) was included. Where there were two or more factors a split-plot or split-split-plot design was used, respectively. The hierarchical order from the whole plot to subplots followed the amount of nitrogen fertilization, density and genotypic composition of the stand. In the site experiment (V) the site was in the whole plot and genotypic composition in the subplot. The genotypic composition of the stand refers to pure stands of species (barley-oats) or genotypes (barley-barley) and mixtures. The number of blocks varied from three to four.

\subsection{Location and management of the experiments}

All the barley varietal mixtures (I-II) were located at the Experimental Farm of the University of Helsinki in Helsinki Viikki $\left(60^{\circ} 13^{\prime} \mathrm{N}, 25^{\circ} 00^{\prime} \mathrm{E}\right)$. Some of the barleyoats trials (III) were carried out at Viikki as well and some (IV and V) on the Kotkaniemi Experimental Farm of Kemira Oy in southern Finland $\left(60^{\circ} 22^{\prime} \mathrm{N}, 24^{\circ} 22^{\prime} \mathrm{E}\right)$.

The mixtures were mechanically mixed before sowing. The proportion of components is based on the number of plants per unit area. The size of the plot in Viikki was $10 \mathrm{~m}^{2}$ and in Kotkaniemi $15 \mathrm{~m}^{2}$ (IV) or $30 \mathrm{~m}^{2}$ (V) with rows spaced at $12.5 \mathrm{~cm}$. The levels of nitrogen fertilization and densities are given in Table 1 . The fertilizers were placed $8 \mathrm{~cm}$ deep in the soil before sowing.

The crops were kept free of weeds by applying once at the time of shoot emergence the herbicide Actril S (2-3 liters/ha mixed with 300 liters of water) containing MCPA (235 $\mathrm{g} / \mathrm{l})$, dichlorprop (184 g/l), ioxynil (38 g/l) and bromoxynil $(24 \mathrm{~g} / \mathrm{l})$. All the plots of each trial were harvested at the same time when the grain moisture of the latest variety was below $30 \%$.

\subsection{Analysis of the stands and yield}

The early growth and development of the components were observed both visually and by determining the phytomass (I, III), leaf area (I) height (I) and tillering pattern (I). The number of generative shoots was also counted in some trials (I-IV).

The harvested grain yields from all the mixtures in each trial were separarated into the components of the stand. The results were used to determine the relative yields (RY), relative yield totals (RYT), land equivalent ratio (LER), competitive ratio (CR) and a linear regression model.

The protein content $(\%)$ of the grain was determined by the Kjeldahl method (IV, V) and the protein yields were calculated.

The 1000-grain weights of the mixtures and components were determined in some trials. The number of grains per ear was calculated from the grain yield per plant, the number of generative shoots per plant and the 1000-grain weights.

\subsection{Mathematics and statistics}

Relative yields (RY) and relative yield totals (RYT) were calculated according to the method of de WIT and van den BERG (1965), land equivalent ratio (LER) according to TRENBATH (1976) and competitive ratio (CR) according to WILEY and RAO (1980). The method of calculation for RY, RYT and CR is presented in (I) and for LER in (II). The indices were calculated from the average values of replications. No statistical analysis was made for RY, RYT, LER and CR because no single method has been adopted for quantifying interactions (PEARCE and EDMONDSON 1984, VANDERMEER 1990 p.26). The expected yield of a mixture is the sum of the yields of 
the components grown in pure stand divided by the number of components in a given mixture.

The grain and protein yields per area of each experiment (pure stands, mixtures) were subjected to an analysis of variance. The analysis of variance was used also for the analysis of other data described in the original papers. The structure of the analyses of variance depended on the experimental design, and the analyses were performed according to STEEL and TORRIE (1980). If the analysis of variance revealed significant differences, mean separation was accomplished by Tukey's honestly significant difference test (HSD) $(\mathrm{P}=0.05)$ according to STEel and Torrie (1980 p.185).

In order to evaluate the dependence of reciprocal yield per plant on the density of the components, multiple linear regression was performed (II, III) as described by WRIGHT (1981) and SPITTERS (1983). The form of the regression model for the genotype 'a' was $1 / \mathrm{Wa}=\mathrm{Aa}+\mathrm{BaaNa}+\mathrm{BabNb}$, where $1 / \mathrm{Wa}$ is the reciprocal grain yield of an individual plant, $\mathrm{Aa}$ is the reciprocal of the theoretical maximum yield of an individual, Baa describes the influences of intragenotypic competition, Bab describes the influences of intergenotypic competition and $\mathrm{Na}$ and $\mathrm{Nb}$ are the plant densities of the genotypes.

The analysis of linear regression was carried out with the statistical package Stat 80 (HP-1000). The number of functional units, i.e. number of plants per unit area used as independent variables in regression, was that existing at the beginning of the period over which the competition effects were studied. Thus the number of functional units was independent of the competition effects studied. Although tertiary mixtures were included in the trials, the data were inadequate for the analysis so that only binary mixtures were included in the reciprocal model.

\section{RESULTS AND DISCUSSION}

\subsection{Applicability of the linear regression model to studies on the competition and grain yield advantage of mixtures}

In the present studies of barley-barley (II) and barley-oats mixtures (III), parameters obtained by applying the regression model were used to define various competitive relationships between components and to evaluate the usefulness of mixtures. The regression equations accounted for $90-96 \%$ of the variation in grain yield (the inverse yield/plant) of the genotypes $\left(R^{2}=0.90-0.99\right)$.

Mixture components. The intragenotypic parameter of one genotype in the linear regression model was always greater than the intergenotypic parameter. In most of the barleyoats mixtures and in all the barley varietal mixtures the intragenotypic parameter of the other genotype in the same mixture was smaller than the intergenotypic parameter. Thus when $\mathrm{Bab}>\mathrm{Baa}$ and $\mathrm{Bbb}>\mathrm{Bba}$ in the regression equation and b's yield in pure stand was greater than a's (Baa $>\mathrm{Bbb})$, the least productive component in pure stand suffered from competition in the mixture. This is an indication of a certain degree of compensation (MEAD and RILEY 1981).

According to the model, the Montgomery phenomenon $(\mathrm{Baa}>\mathrm{Bab}$ and $\mathrm{Bbb}<\mathrm{Bba}$ with the pure yield of ' $b$ ' larger than that of 'a') occurred in some barley-oats mixtures and also in some barley-barley mixtures. Since according to the model one defines the most productive component in pure stand on the basis of a parameter describing intragenotypic competition within an equation, one can arrive at misleading estimates. This was especially liable to occur in barley-oats mixtures in 1983 where the maximum yield (an asymptotic point) fell outside one's field of observation.

In the barley-oats mixture at the lowest level of nitrogen fertilization in 1983 the intragenotypic competition of both components was less than the intergenotypic competition (Bab $<\mathrm{Baa}$ and $\mathrm{Bba}<\mathrm{Bbb}$ ). This indicates that the 
mixture yields of both components were relatively greater than the pure stand yield of the components. In this situation it was a question of mutual cooperation according to MEAD and Riley (1981). It is important to note the fact in the case of mutual cooperation the mixture may overyield as the actual yields also showed. One concludes from the equation that overyielding depends upon the ratio between the pure stand yields of the components and upon the degree of mutual cooperation. Thus in the extreme case where two components exploit completely separate environmental resources, then $\mathrm{Bab}=\mathrm{Bba}=0$, and each behaves exactly as if it were growing in monoculture at half the normal density, resulting in considerable mixture advantage.

When the parameter describing intergenotypic competition for one genotype was less than that describing intragenotypic competition $(\mathrm{Bab}<\mathrm{Baa}$ ) the grain yield of a genotype in the mixture was relatively greater than genotype's pure stand yield (see for example barley cv. Arra in the mixture with barley cv. Pomo at the high level of nitrogen fertilization). This was not only over a particular range of densities; a genotype responded also more readily to increases in stand density in mixture than in monoculture. This indicates, as was also observed by WRIGHT (1981), that the proportion $(\mathrm{L})$ of component a's maximal, asymptotic yield in a mixture with b (the densities of both components being equal) will be attained when the density (p) of a in the mixture, $\quad \mathrm{pmi}=\mathrm{Aa} /(\mathrm{Baa}+\mathrm{Bab})(1-\mathrm{L}) / \mathrm{L}$, which will be larger than $1 / 2$ pmo when $\mathrm{Bab}<\mathrm{Baa}$ for 'a'. It follows that in order for a given proportion of the maximum yield of a genotype to be attained, a genotype would have to be present at higher densities in the mixture than in pure stand (pmi $>1 / 2$ pmo). Thus when the total density of the stand exceeded a certain level, the yield of a genotype in a mixture increased, whereas the yield of a genotype in a pure stand of similarly increasing total density levelled off. In the barley-oats mixture at the lowest nitrogen level in 1983 both
$\mathrm{Bab}<\mathrm{Baa}$ and $\mathrm{Bba}<\mathrm{Bbb}$. Thus one may assume according to the model that the optimal overall density of the mixture was larger than the optimal densities of either monoculture.

Further exploitation of the potential of the material is somewhat precluded by the fact that the value of $\mathrm{A}$ (the reciprocal of the theoretical maximum yield of an individual) in the regression was insubstantial. This caused uncertainty in determining the density which would result in maximum yields of the components, either in optimal proportions in a mixture or in pure stand. To obtain reliable estimates of $\mathrm{A}$, one would need to lay out trials including extremely dense and extremely sparse stands for measuring yield/plant. Only then could the regression model be adjusted to give precise results. The greater the degree of precision required, the greater the amount of data and the more complex the model needed.

As the stand density decreased, for example in the mixture of barley cv. Arra and barley cv. Agneta at high level of nitrogen fertilization, the competitive ratio calculated according to the replacement series analysis approached unity. This indicates that intragenotypic competition should approach intergenotypic competition for both components. However, the parameters obtained from the regression model are independent of the stand density. This suggests that competition between components was not always linearly related to cropping density in the present study. Thus the regression model applied in this way described competition only in relatively dense stands, as observed also by WRIGHT (1981).

When intragenotypic competition outweighed intergenotypic competition in the mixture, the increasing frequency of an aggressor (barley) increased the barley's relative yield (RY) relatively less than the decrease in the relative yield (RY) of a subordinate (oats). Then the competitive ratio of an aggressor (barley) decreased as the actual values of competitive ratio indicated. Thus it is important to note that one can predict from the regression model how the competitive ratio of the 
de Wit model is dependent on the intra- and intergenotypic competition in the mixture although the competitive coefficients of the regression model are independent of the proportions of the components. Recently FIRBANK and WATKINSON (1990) also observed that the competitive equivalence between plants of different species may also vary with frequency and density. This may be because the morphologies of the plants respond in different ways to different combinations of frequency and density.

Since both analyses on replacement series after the model of de WIT (1960) and the regression models gave similar results as regards competitiveness of the genotypes (competitive ratio, relative competitive ability), one can employ either model, bearing in mind their respective limitations as discussed in (II) and (III). If one is aiming to make a fundamental analysis of competition, particularly of the intensity of competition, one should adopt the regression model and use addition series. If one's aim is to make a preliminary screening of components with, mainly mixed cropping in view, and provided that the mixtures crop near-optimally over a wide range of densities as is the case with cereals, replacement series should suffice. Also the similarity in size of individual plants is an important assumption in the replacement series design (de WIT 1960, Harper 1977 p. 291-302) to ensure that density and yield are not confounded (KEDDY 1989 p. 116).

Mixture totals. If one takes the mixtures as a whole, intragenotypic competition was stronger than intergenotypic $(\mathrm{Baa} / \mathrm{Bab}>\mathrm{Bab} /$ $\mathrm{Bbb}$ ), both in the barley varietal mixtures in general and in the barley-oats mixtures in 1983. According to SPITTERS (1983), this may indicate the existence of niche differentiation.

In the present study the parameter $(\mathrm{Bab} \times \mathrm{Bba})^{0.5}$ was smaller than either Baa or $\mathrm{Bbb}$ for the respective components in three barley varietal mixtures and in the barley-oats mixtures in 1983 at nitrogen levels of $10 \mathrm{~kg} / \mathrm{ha}$ and $80 \mathrm{~kg} / \mathrm{ha}$. This indicates that a mixture of optimal composition will outyield the pure stand yields of both components, as the actual yields in most cases showed. According to the present results, both the level of nitrogen fertilization and the components of a mixture were important determinants of the parameter $(\mathrm{Bab} \times \mathrm{Bba})^{0.5}$. Thus for further studies one should ideally find components with as low an interspecific or intergenotypic competition as possible, and investigate the environmental variables which determine the magnitude of this competition.

\subsection{Competitive hierarchies in mixtures and the stability of competitive relations}

In most of the mixtures the grain yield of one (or some) of the genotypes in a mixture was higher, and the yield of the other(s) was lower than the pure stand yields, i.e. the relative yields of the components were not equal $(\mathrm{I}-\mathrm{V})$. This indicates that the competition between genotypes was usually asymmetric (KEDDY 1989 p.119, 1990) or one-sided (FIRBANK and WATKINSON 1990), thus producing competitive hierarchies.

Phytomasses measured from the barley-oats mixtures in 1984 (III) showed that the phytomass of barley was greater in admixture than in pure stand, and conversely for oats. Dominance relations determined in the same trial at the end of the growing period suggest the effect of competition having accumulated, assuming that a component's harvest index was the same in the mixture as in pure stand as shown by SPITTER (1979 p. 189-191). The accumulation of competition might be because of snowballing (NEwMAN 1973), which is most likely caused by competition for light and not by direct competition for nutrients (WILSON 1988). WEINER (1986, 1990) has also shown that when above- and below-ground effects are separated, aboveground interactions (competition for light) are asymmetric, wheras below-ground effects (competition for nutrients) are symmetric. When above- and below-ground effects occur 
together, interactions are again asymmetric. Thus the results of the present studies suggest that the observed asymmetry in the mixtures might be predominantly caused by competition for light.

The degree of competitive ability of a genotype varied sometimes from one growing season to another, as shown by the dominance of Hja 673 over Pomo and Agneta in the barley varietal mixtures (I). Likewise in the barley-oats mixtures the competitiveness of barley cv. Agneta varied somewhat depending on e.g. cropping intensity (III) and growing season (III, IV). The competitive relationship between two genotypes was also somewhat influenced by other components in a mixture (I, II). These results suggest that the competitive ability is not necessarily a stable characteristic of a given genotype. PICKETT and BAzzaZ (1978) and RAdosevich and Roush (1990) demonstrated that environmental conditions influenced competitive relationships and caused hierarchies among plant species grown in mixtures to be inconsistent.

In many plants, variation in fitness is not always related to genotype, and much of the variation observed is an environmentally induced variation in phenotypic plasticity (TURKINGTON 1989). In the present studies the grain yield per individual of a component growing in admixture (see for example oats cv. Veli in the mixture with barley cv. Aapo in IV) was even equal to that in pure stand, but the relative proportions of the various yield components differed in the two situations. This indicates that plants at the individual level characteristically showed a plastic response to their environment, whether in pure stand or in a mixture. It is thus understandable that the type of environment, or more specifically the availability of growth factors, has a crucial influence upon the development of individuals of different genotypes. This being so, it becomes very difficult to predict the competitive relations for a combination of components for all sets of environmental conditions.

\subsection{Factors affecting competition between components and competitive ability of a genotype}

The significance of the barley type (two/six-rowed) and the earliness of barley. In barley varietal trial six-rowed (tall-growing, erect, less tillering) barleys as a class were no better as competitors than two-rowed (low-growing, prostate, vigorously tillering) (I). Likewise, early maturing barley varieties were not consistently more competitive than late maturing varieties (I). The results of the barley-oats mixture trials also showed that six-rowed barleys were not more aggressive towards oats than were two-rowed barleys (III, IV). These results are not in accordance with the results of Mitchley and Grubb (1986) and Mitchley (1988) who found a positive correlation between the height of a grassland species and its competitive ability. Thus the results of the present study suggest that there are characteristics other than those studied which determine the genotype's predominance in a mixture.

The significance of the adaptation of a genotype. In a given environment a genotype yielded less in pure stand than other components, but still proved to be dominant in the mixtures, or the converse was true $(\mathrm{I}-\mathrm{V})$. Thus vigour and adaptation did not necessarily determine the competitive ability, agreeing with the other results reviewed by SPITTERS (1979).

It is, however, important to note that barley cv. Agneta, which was unable to exploit its entire genetic potential right from the beginning of the growing period because of low soil $\mathrm{pH}$, proved a poor competitor (II). Similar observations were made by de WIT (1960). This suggests that the poorly adapted and the lower yielding variety may be unfavoured in competition.

The significance of initial development and redistribution of space. The rate and mode of initial development up to the end of the first month of the growing period were examined 
in more detail for the barley varietal trial in 1983 (I) and for the barley-oats mixture trial in 1984 (III). According to these results, the competitiveness for grain yield of a genotype in a mixture usually increased with phytomass (I, II) and culm height (I) accumulated during initial development. It appears that a larger phytomass combined with a taller main culm early in the growing period conferred upon the variety a competitive advantage later on in the season. The strong initial development of barley cv. Arra in particular was the factor which most probably contributed to its competitiveness in all mixtures, irrespective of growing season (I), sowing density (II) or cropping intensity (II). Thus the rate of initial development seems to play an important role in competition, as shown also in other studies (Fischer and Miles 1973, Harper 1977 p.354, SpItTers and van den Berg 1982, SPITTERS 1984, FirbanK and WATKINSON 1985, RouSH and RADOSEVITCH 1985, 1987, SPITTERS and Kramer 1986, HákansSon 1991).

Owing to its rapid initial development the genotype such as barley cv. Arra (I, II) was in a position to exploit growth factors first when these were most needed (PERBy and JENSEN 1984). The rapid uptake of nutrients especially nitrogen by one of the varieties in a mixture might deprive other components. According to Metivier and Dale (1977), a period of deprivation lasting a few days will adversely affect assimilation and thereby dry matter accumulation. On the other hand, effective uptake of nitrogen at the beginning of the growing period may enhance the photosynthetic efficiency of a variety, e.g. due to a higher activity of Rubisco (MAKINO et al. 1984), and thus promote the expansive growth of a component in the mixture. Later in the growing season the taller and early developing variety like barley cv. Arra might not only have access to incoming light for its own growth, but might simultaneously reduce the growth of the smaller plant by setting up a positive feedback loop whereby the larger plant continually improves its access to light and the smaller plant was increasingly denied access to it as shown by KEDDY and SHIPLEY (1989). Reduced access to light will reduce carbohydrates available for root growth, thereby reducing rates of nutrient uptake (TILMAN 1988). CALDWELL et al. (1987) illustrated that shading or defoliation can reduce root growth and mineral uptake even within $24 \mathrm{~h}$.

In addition, component analyses of the yield indicated that competitive relations were determined at a relatively early stage of development. The competitive situation which was thus brought about affected mainly the degree of tillering and kernel number/ear (III, IV). Similar observations were made by e.g. SPITTERS (1979) and VALENTINE (1982).

In the trials, the competitive relations were examined between different barley varieties and a single oats variety (IV). All the barley varieties emerged before the oats. However, the low-growing barley cv. Aapo, which began culm extension late, was not more competitive than oats at the high level of nitrogen fertilization. This suggests that when the productivity of the stand increased due to the increase of nitrogen fertilization, competition for light intensified, whereas competition for nutrients became less important, as shown by Tilman $(1982,1988)$. This confirms that the slow initial development of oats does not always result in its suppression in a mixture; rather that by competing more effectively for light in later stages of its development by virtue of its greater height, oats can stabilize dominance relations. This might also indicate the redistribution of space. According to SPITTERS (1984), the relative differences among the genotypes in a mixture are only maintained if they have the same relative growth rates during the course of time. Thus space may be redistributed in favour of genotypes with higher relative growth rates.

Among the yield components examined, kernel weight generally showed the least variation (IV). The stability of kernel weight was probably a result of this character's being under stricter genetic control than other components of yield (HARPER 1977 p. 664-71). If environmental conditions are unfavourable 
for the development of yield components other than kernel weight, very little compensatory effect is possible with respect to kernel weight. Thus the redistribution of space is more likely to occur before the grain filling period. Factors that determine the opportunity and capacity for compensatory responses include physical constraints on plant growth, resource constraints on plant growth, flexibility in internal resource allocation and type of intraspecific density dependence (LouDA et al. 1990).

The significance of differences in allocation of genotypes. In the barley varietal mixture trial of 1983 there were no significant differences between the phytomasses or culm heights of $\mathrm{Hja} 673$ or Agneta (I). This indicates similar rates of initial development for these genotypes. However, Agneta had become more dominant than $\mathrm{Hja} 673$ by the end of the growing period. According to measurements, Agneta allocated relatively more assimilates to the main culm than did $\mathrm{Hja} 673$, and the leaves on Agneta's main culm were wider than in $\mathrm{Hja}$ 673. It is therefore likely that Agneta competed more successfully for light than $\mathrm{Hja} 673$. This suggests that in cases where rates of initial development of varieties are similar relatively small morphological differences, caused by differential allocation of resources, may contribute to the dominance of a variety in a mixture.

The significance of a biotic stress. In the mixture trial of barley cv. Agneta and oats cv. Veli in 1984 (III) the competitive ability of oats was reduced compared to other mixture trials of the same cultivars (III, IV, V). The strongly reduced competitive ability of oats might be due to an infestation of frit fly (Oscinella frit) which retarded the formation of the main culm of oats and thus lowered the capacity of oats to compete at least for light. The results suggest that competition for resources, and thereby competitive relations between components can be influenced not only by abiotic stress factors, but by biotic ones as well. This was also shown by HARP. ER (1977 p.401), Clay (1990), ConNell (1990),
LoudA et al. (1990). On the basis of the present material one cannot estimate, however, what were the relative contributions of competition for resources (real competition) and of biotic stress factors (apparent competition) in determining competitive relations. In other studies reviewed by CRAWLEY (1983) it was shown that if the competitive dominant is preferentially fed upon, then a less competitive species can increase, and species diversity is promoted, but if the less competitive species is preferentially fed upon then it is doubly disadvantaged.

The significance of the productivity gradient. In the barley-oats mixture trial of 1983 (III), the degree of dominance of barley increased as the productivity of the stands responded positively to nitrogen fertilization. At the lowest level of nitrogen oats was even more productive in pure culture (III, Table 4) and more dominant than barley (III, Fig.2). These results suggest that the oats $\mathrm{cv}$. Veli might be a better competitor on a nutrientpoor soil by virtue of its superior ability to exploit soil nutrients, whereas barley cv. Agneta might compete better for light on account of its faster initial development but also partly because of its pronounced response to nitrogen fertilization. These results are in accordance with the resource competition theory (TILMAN 1982, 1988) which predicts that genotypes which compete efficiently for light become more abundant as overall productivity rises, while genotypes which exploit nutrients more effectively than their neighbours increase in abundance as the environment becomes less productive. Long-term pure culture trials in Finland also demonstrated in general that oats responded to increased fertilization more slowly than barley, oats producing larger yields than barley in a low fertilization environment (VERMEULEN 1991).

Generally, species which compete more effectively for soil resources allocate relatively more to the roots than to the stems (TILMAN 1988). The relatively superior competitive ability of oats on nutrient-poor soils may therefore derive from differences in allocation be- 
tween the species. During the early stages of development oats might invest relatively more in the roots than to the stems compared to barley as the results of Syme and Bremer (1968) suggested. This would, however, put oats at a disadvantage as regards competition for light especially in an environment with a high nitrogen level. Conversely, on a nutrientpoor soil barley might invest relatively more in its root system than in the stems, compared to its behaviour on a nutrient-rich medium as shown by HANSSON (1987). This would reduce barley's ability to compete for light at later stages of development on a nutrient-poor soil. According to Bцoom et al. (1985), allocation is adjusted within roots or shoots in response to environmental stress so as to maximize efficiency for capturing the most limiting resource. In addition to differences in root vs. shoot allocation, also differences in leaf structure could lead to a tradeoff between responsiveness to increased soil nutrients and increased solar radiation (HoRn 1971, MoONEY and Gulmon 1979).

It is, however, important to note that the dominance of barley cv. Agneta did not always increase when the production conditions were improved by the increase of availability of soil resources (V). Neither was oats cv. Veli more dominant in low productivity conditions than barley, although in low productivity conditions the pure stand yield of oats was greater than that of barley. One can, however, postulate that oats was able to exploit soil resources more effectively in pure stand in low productivity conditions but not in the mixture owing to its slower germination compared to barley. This might render oats a less effective competitor for light even in low productivity conditions. Thus the results suggest that the balance of early development between competing species has a fundamental effect on subsequent competition for light and soil resources along the productivity gradient.

In varietal mixture trials, barley cv. Arra (II) as well as barley cv. Agneta (I) responded to increased nitrogen fertilization by an increase in dominance. Pomo was a variety which responded weakly to increase of nitrogen fertilization both in mixtures and in monocultures (I, II). This suggests that the response of different varieties to the availability of resources may also vary, thus affecting their competitive ability.

\subsection{Yield advantages}

Grain yield. The present results (I-II) showed that the yield of the barley varietal mixture was often equal to the means of the components grown in monoculture but also exceeded them. It was uncommon for a mixture to yield less than the mean of its components. These results agree well with the earlier works reviewed by Simmonds (1962), TRENBATH (1974) and Wolfe (1985). The present results are also in accordance with recently published studies of barley varietal mixtures by BAKer and Briggs (1984), Houmoeller et al. (1986), Karjalainen and Hirvola (1987), GiefFers and Hesselbach (1988), Ibenthal et al. (1988) and Aufhammer and Stutzel (1989).

The results revealed that the yield advantage of the barley varietal mixture, as determined by relative yield total (RYT), was usually greater than unity under suboptimal production conditions (I, II). In high productivity conditions the relative yield total was close to unity (I, II). The results of these experiments in most cases are well compatible with the de Wit competition model, agreeing with the results of earlier barley varietal experiments (e.g. Sandfaer 1970, Blijenburg and SNEEP 1975, SPITTERS 1979). Thus highly adapted barley varieties appear to compete for the same resources, and the grain yield advantage of such mixtures is marginal.

The grain yield results of barley-oats mixtures showed that mixtures in general yielded equal to or more than the mean of the components grown alone (III, IV, V). The mixture of barley cv. Agneta and oats cv. Veli overyielded statistically significantly in 1983 (III). In some trials the mixture of barley $\mathrm{cv}$. 
Agneta and oats cv. Veli also overyielded under high productivity conditions, although the differences were not statistically significant $(I V, V)$. Relative yield totals were usually equal to or greater than unity (III, IV, V). In the barley-oats mixture trials the effect of density and proportion of the components (III) and the effect of the level of nitrogen fertilization (III, IV) upon the relative yield total were not clear. In general, these results suggest that the mixtures of barley and oats may use resources more efficiently than monocultures but an as yet unpredictable modifying effect caused by environmental factors. The results of other experiments in respect to productivity of mixtures of barley and oats have also been quite variable (for example Syme and Bremner 1968, Bebawi and Naylor 1978, TAYlor 1978, Fejer et al. 1982).

It is important to note that dominance relations between the components influenced the formation of yield advantage. If one takes overyielding as one's criterion, overyielding will never be obtained as long as the component which is less productive in pure stand is dominant, and as long as the mixture's relative yield total is close to unity. Furthermore, the actual yield of the mixture will be smaller than expected. Thus a cultivar which is almost invariably dominant, such as Arra in the barley varietal mixtures (I, II) or Agneta in the barley-oats mixtures (III, IV, V), may be unfavourable for overall yield formation. This applies especially to conditions in which a cultivar produces less in pure stand than the other components, and in which the relative yield total of the mixture is near unity.

Overyielding is also impossible whenever the higher yielding component in monoculture is dominant in the mixture, and the relative yield total is close to unity. In this case, though, the actual yield can be higher than expected, as e.g. in the barley-oats mixtures in 1984 (III). The use of such a mixture on the basis of overall yield is unwarranted, however, since a yield as great as that of the mixture could have been obtained by planting the components in pure stand in the ratio of the components' relative yields.

If, however, the relative yield total of the mixture exceeds unity, the mixture can overyield, and the actual yield can be greater than expected, irrespective of dominance relations between the components. The central issue of whether or not to use a mixture depends upon the conditions under which the relative yield total will exceed unity. Since the results of the present studies showed that in both the intraand interspecific mixtures the relative yields of the components as well as pure stand yields varied considerably, it is difficult to predict yield advantage for mixtures formulated more or less at random and under varying environmental conditions. The establishment of such an advantage is nevertheless a precondition for exploiting a mixture in practical farming.

Before a given mixture can be recommended in practice, extensive trials need to be carried out to allow estimation of at least the relative yield total, since the ratio of actual and expected yields on its own does not give a comprehensive picture of the mixture's possible yield advantage. In other words, the actual yield of the mixture may be higher than the expected yield merely because the component yielding better in pure stand is dominant.

From a methodological point of view it is also important to note that the relative yield total decreased approaching unity as density was increased (II). In addition, the calculated land equivalent ratio value (LER) indicated that the yield advantage would have been marginal. Thus a simple replacement series trial cannot unequivocably demonstrate this to be the case, as the overall density is predetermined and does not necessarily lie at the optimal point of the yield-density function for all the components in pure stand or for the various mixtures (ConNolly 1986, HẢKANSSON 1988). This means that even when the relative yield total is greater than unity, one cannot be certain that the mixture was really superior to the monocultures unless maximal yield has been evaluated under the appropriate conditions.

Protein content and protein yield. One ad- 
vantage of mixed cropping may be a higher protein content of the yield which may be due to the mixture's superior ability to exploit nitrogen (WILLEY 1979). The results of the present study did not indicate, though, that the protein content of a mixture was any higher than that of the monocultures (V). Although the protein content of the grain yield of oats cv. Veli in the mixture with barley cv. Agneta was generally higher than for the monoculture, the protein content of the grain yield of barley was correspondingly lower for the mixture than for the pure stand (IV, V). Thus barley's ability to produce a higher mixture grain yield than oats compensated for the higher protein content of oats in the mixture yield.

The protein yield of mixtures did not differ statistically significantly from the yield of the highest yielding component grown alone $(\mathrm{IV}, \mathrm{V})$. However, the ratio of actual and expected protein yield and the relative protein yield total were usually slightly greater than one, indicating that some yield advantage may have been achieved.

\subsection{Stability of mixtures}

The literature suggests the idea that mixtures may crop more stably than monocultures (Wolfe 1985). Still, general ideas on the stability of mixtures are partly conflicting (e.g. Clay and Allard 1969, Trenbath 1974, LANG et al. 1975, Shorter and Frey 1979, EISENBERG 1980).

In the present studies the yield of a given mixture varied less than the most variable yield of pure stand, and they varied more than the least variable pure stand yield as determined by the coefficient of variation (I). In some cases the variation in grain yield might even be smaller for the mixture than for the least variable component in pure stand. An example is provided by the variation in the yields of Agneta, Pomo and their mixtures in five trials (I, II) in which comparable cropping intensities were used $(80-100 \mathrm{~kg} \mathrm{~N} /$ ha and 500
- 600 kernels sown $/ \mathrm{m}^{2}$ ) (Mixture $\mathrm{CV}=8.8$, Agneta CV $=11.7$, Pomo CV $=14.2$ ). The coefficient of variation calculated on mean yields of the mixture trials involving oats cv. Veli and barley cv. Agneta (III, IV, V) shows that a mixture was not more stable than the most stable monoculture (barley $\mathrm{CV}=5.3$, mixture $\mathrm{CV}=13.7$, oats $\mathrm{CV}=27.7$ ).

Thus in the present studies not all mixtures were more stable than the most stable component. This is readily understandable in view of the fact that the dominance relations between components can alter from one environment to another irrespective of differences between monoculture yields of these components. For instance, the grain yield of a mixture of two components may vary more than the yields of either component in monoculture solely, because the dominance relations vary with a change in environment while grain yields in pure stands remain fairly stable.

A thorough investigation of stability is precluded by the limitations of the material, or more specifically by the small number of environments used. To gain a comprehensive view of the stability of mixtures would have required a wider series of trials enabling one to apply rigorous methods of analyzing genotype-environment interaction. However, one may encounter difficulties in selecting of appropriate method of analysis, because the different stability parameters may result in very different stability rank orders of the stands as shown by HUHN and LEON (1985).

\section{SUMMARY AND CONCLUSIONS}

In this study, competition and yield advantage in barley varietal mixtures and in barleyoats mixtures were investigated. The components of the mixtures were officially recognized cultivars used in commercial cropping. The trials were carried out on the trial field of the Department of Crop Husbandry, University of Helsinki, Viikki and on the Kotkaniemi trial field, Kemira Oy in 1983-1986.

The competition between two components 
of an addition series design was defined according to two approaches, one based on the de Wit model and the other upon a linear regression model. Competitive relations in replacement series design were examined on the basis of the de Wit model.

Three approaches were used to assess the grain and protein yield advantage of mixtures:

a) comparing the yield of the mixture with the yield of the components grown in pure stands.

b) calculating the ratio between the actual and expected yield

c) calculating the relative yield total (RYT). The coefficient of variation was used as a criterion of stability.

\section{Competition}

* Both models of competition agreed as to which component was the dominant and which was the subordinate in the mixture.

* Comparative trials revealed that competitive relations may depend on stand density.

* The competition coefficients from regression analyses depicted competition between components better in a dense than in a sparse stand.

* It was possible to assess the effect of altering mixture ratio on yield per individual of the components from the relative contributions of intra- and intergenotypic competition, as measured by the components' regression coefficients, even though these competition indices are independent of the mixture ratio.

* Competitive ability did not depend directly on individual characters of the genotype, such as rate of initial development, earliness, culm height, tillering capacity or grain yield in monoculture (adaptation). A good combination of characters from the viewpoint of competition is provided by barley cv. Arra with its rapid initial development and rapid culm growth.

* Competitive relations between the species and between the barley varieties were in most cases inconsistent varying from one environment to another.

* The dominance of an aggressor usually increased with increasing nitrogen fertilization especially when the total density was high.

* Competition affected all the components of yield with kernel weight being least affected.

\section{Grain yield advantage}

* The results of some mixtures of barley and oats showed that the ratio of actual and expected yields exceeded unity but the relative yield total of the same mixtures was even lower than unity. This was because the yield of the dominant component was higher than the yield of the subordinate component when the components were grown in pure stands. Thus from a methodological point of view when one evaluates the yield advantage of mixtures at least the relative yield total should be considered. This point becomes especially relevant in cases where there are considerable differences between the yield of the components grown in pure stands and the competitiveness of one component differs from that of the other.

* None of the varietal mixtures overyielded statistically significantly. Especially at low densities some varietal mixtures gave yield advantage as assessed by relative yield total $($ RYT $>1)$. Also the relative yield total was greater than one under conditions where the nitrogen fertilization was not optimal. The results of the barley varietal trial repeated during three successive years indicated that the relative yield total of a given mixture fluctuates around unity. Thus at optimal conditions the yield advantage was marginal.

* The results of the barley-oats mixture trials showed that the mixture of barley and oats may overyield statistically significantly. Relative yield totals were in most cases equal to or greater than unity, the latter occurring even in high productivity conditions. This suggests that mixtures of barley and oats may use resources more efficient- 
ly than monocultures and yield advantage may be achieved by growing mixtures instead of monocultures. However, large scale field experiments are needed before such combinations can be used in practice.

\section{Protein yield advantage}

* The protein yield of mixtures did not differ statistically significantly from the yield of "the highest yielding component grown alone. However, the ratio of actual and expected protein yield and the relative protein yield total were usually greater than one indicating that some yield advantage may be achieved.
Stability of grain yield

* The mixtures were not consistently more stable than monocultures.

\section{References}

Allard, R.W. \& Adams, J. 1969. Population studies in predominantly self-pollinating species. XIII. Intergenotypic competition and population structure in barley and wheat. Amer. Nat. 103:621-645.

Aufhammer, W. \& Stutzel, H. 1989. Sorten-Mischungeffekte in Wintergerstenbeständen in Abhängigkeit von Standort und Produktionintensität. J. Agron. Crop Sci. 162:180-191.

Aufhammer, W., Kubler, E. \& Stutzel, H. 1984. Effekte der Sortenmischung auf die Ertragsbildung von Gerstenbeständen. J. Agron. Crop Sci. 153:385-397.

BAKER, R.J. \& Briggs, K.G. 1984. Comparison of grain yield of uniblends and biblends of 10 spring barley cultivars. Crop Sci.24:85-87.

Bebawı, F.F. \& NaYlor, R.E.L. 1978. Yield performance of mixtures of oats and barley. New Phytol. $81: 705-710$.

Begon, M., Harper, J.L. \& Townsend, C.R. 1986. Ecology. Individuals, Populations and Communities. 876 p. Blackwell Scientific Publications. Oxford.

Berendse, F. 1982. Competition between plant populations with different rooting depths. III. Field experiments. Oecologia 53:50-55.

BERG, J.P. van den. 1968. An analysis of yields of grasses in mixed and pure stands. Versl. Landbouwk. Onderz. 714:1-71.

Blijenburg, J.G. \& Sneep, J. 1975. Natural selection in a mixture of eight barley varieties grown in six successive years. 1. Competition between the varieties. Euphytica 24:305-315.

Bloom, A.J., Chapin, F.S.III \& Mooney, H.A. 1985. Resource limitation in plants - An economic analogy. Ann. Rev. Ecol. Syst. 16:363-392.

BrAaKHEKKE, W.G. 1980. On coexistence: A causal approach to diversity and stability in grassland vegetation. Agric. Res. Rep. 902:1-164.

Burdon, J.J. 1987. Diseases and Plant Population Biology. Cambridge Studies in Ecology. 224 p. Cambridge
University Press, Cambridge, England.

Caldwell, M.M. \& Richards, J.H. 1986. Competing root systems, morphology and models of absorption. In: Givnish,T.J.(ed.). On the Economy of Plant Form and Function. Proc. Sixth Maria Moors Cabot Symposium, Evolutionary Constraits on Primary Productivity. p. 251-273. Cambridge University Press. Cambridge.

Caldwell, M.M., Richards, J.H., Manwaring, J.H. \& Eissenstat, D.M. 1987. Rapid shifts in phoshate acquisition show direct competition between neighbouring plants. Nature 327:615-616.

CLAY, K. 1990. The impact of parasitic and mutualistic fungi on competitive interactions among plants. In: Grace,J.B. \& Tilman,D. (eds.). Perspectives on Plant Competition. p. 391-412. Academic Press, Inc. New York.

Clay, R.E. \& Allard, R.W. 1969. A comparison of the performance of homogenous and heterogenous barley populations. Crop Sci. 9:407-412.

ConNell, J.H. 1990. Apparent versus wreal» competition in plants.In: Grace,J.B. \& Tilman,D. (eds.). Perspectives on Plant Competition. p. 9-26. Academic Press, Inc. New York.

Connolly, J. 1986. On difficulties with replacementseries methodology in mixture experiments. J. Appl. Ecol. 23:125-137.

Connolly, J. 1987. On the use of response models in mixture experiments. Oecologia 72:95-103.

Cоттам, D.A. 1985. Frequency-dependent grazing by slags and grasshoppers. J.

Ecol. 73:925-933.

Crawley, M.J. 1983. Herbivory. The Dynamics of Animal-Plant Interactions. Studies in Ecology 10. 437 p. Blackwell Scientific Publications. Oxford.

DobBen, W.H. van. 1953. Proefnemingen met mengcultuur van haver en gerst in 1952. Report on interprovince trials 42 (mimeographed). Wageningen:Central Insti- 
tute for Agricultural Research. (Ref. Taylor, B.R.1978).

Donald, C.M. 1963. Competition among crop and pasture plants. Adv. Agron. 15:1-118

Fejer, S.O., Fedak, G. \& Clark, R.V. 1982. Experiments with a barley-oat mixture and its components. Can. J. Pl. Sci. 62:497-500.

EISENBERG, B.E. 1980. Screening for competition effects amongst genotypes of barley, oats and lupins. Crop Production 9:39-47.

Firbank, L.G. \& WAtKInson, A.R. 1985. On the analysis of competition within two-species mixtures of plants. J. Appl. Ecol. 22:503-517.

Firbank, L.G. \& Watkinson, A.R. 1990. On the effects of competition: From monocultures to mixtures. In: Grace, J.B. \& Tilman, D.(eds.). Perspectives on Plant Competition. p. 166-192. Academic Press, Inc. New York.

Fischer, R.A. \& Miles, R.E. 1973. The role of spatial pattern in competition between crop plants and weeds. A theoretical analysis. Mat. Biosci. 18:335-350.

FitTER, A.H. 1977. Influence of mycorrhizal infection on competition for phosphorus and potassium by two grasses. New Phytol. 79:119-125.

Fowler, N.L. 1990. Disorderliness in plant communities: Comparisons, causes and consequences. In: Grace, J.B. \& Tilman, D. (eds.). Perspectives on Plant Competition. p. 291-306. Academic Press, Inc. New York.

GiBson, C.C. 1986. The population and community biology of Rhinanthus minor L. Ph.D. Thesis. Univ. of East Anglia, Norwich, England. (Ref. Firbank, L.G. and Watkinson, A.R. 1990.)

Gieffers, W. \& Hesselbach, J. 1988. Krankheitsbefall und Ertrag verschiedener Getreidesorten im Rein- und Mischanbau.I.Sommergerste (Hordeum vulgare L.). Z. Pfl.krankheiten Pfl.schutz 95:46-62.

Gilliver, B. \& Pearce, S.C. 1983. A graphical assessment of data from intercropping factorial experiments. Exp. Agric. 19:23-31.

GoldBerG, D.E. 1990. Components of resource competition in plant communities. In: Grace,J.B. \& Tilman,D. (eds.). Perspectives on Plant Competition. p. 27-49. Academic Press, Inc. New York.

Grime, J.P. 1979. Plant Strategies and Vegetation Processes. 222 p. Wiley \& Sons. London.

HákAnsson, S. 1983. Competition and production in short-lived crop-weed stands. Density effects. Swed. Univ. Agric. Sci., Dept. Pl. Husb. Rep. 127. 85 p. Uppsala.

Häkansson, S. 1988. Competition in stands of short-lived plants. Density effects measured in three-component stands. Swed. Univ. Agric. Sci., Dept. Crop Production Sci., Crop Production Sci. 3. 181 p. Uppsala.

Hakansson, S. 1991. Growth and competition in plant stands. Swed. Univ. Agric. Sci., Dept. Crop Production Sci., Crop Production Sci. 12. 241 p. Uppsala.

Hall, R.L. 1974. Analysis of the nature of interference between plants of different species.II. Nutrient rela- tions in a Nandi Setaria and Greenleaf Desmodium association with particular reference to potassium. Aust. J. Agric. Res. 25:749-756.

Hansson, A.-C. 1987. Roots of arable crops: Production, growth dynamics and nitrogen content. Swed. Univ. Agric. Sci. Depart. Ecol. Environmental Res. Rep. 28. 28 p. Uppsala.

Harper, J.L. 1977. Population Biology of Plants. 892 p. Academic Press. London.

Harrabi, M.M., Laribi, A. \& Bouslama, M. 1986. Stability and yield performance of some barley (Hordeum vulgare L.) cultivars and mixtures. Rachis, Barley and Wheat Newsl. 5:11-16.

Horn, H.S. 1971. Adaptive Geometry of Trees. Monographs in Population Biology 3. Princeton University Press, Princeton.

Houmoller, M.S., Henneberg, U., Olsen, C.C., Stolen, O. \& Welling, B. 1986. Sortsblandinger af vinterbyg 1983-85. Tidskr. Planteavl.90:15-26.

Huhn, M. \& LeON, J. 1985. Genotype x environment interactions and phenotypic stability of Brassica napus. Z. Pfl.zuchtg. 95:135-146.

Ibenthal, W-D., Gobel, M., Willnecker, G. \& BernHOLD, L. 1988. Ertragsniveau, Krankheitsbefall und Mehltauvirulenz in Sortenmischungen von Sommergerste (1984-1986). Z. Pfl.krankheiten Pfl.schutz 95:561-571.

INOUYE, R.S. \& Schaffer, W.M. 1981. On the ecological meaning of ratio (de Wit) diagrams in plant ecology. Ecology 62:1679-1681.

Karjalainen, R. \& Hitvola, S-L. 1987. Performance of cultivar mixtures under northern growing conditions in Finland. Barley Genet. V:719-725.

Keddy, P.A. 1989. Competition. 202 p. Chapman and Hall. London.

Keddy, P.A. 1990. Competitive hierarchies and centrifugal organization in plant communities. In: Grace,J.B. \& Tilman,D. (eds.). Perspectives on Plant Competition. p. 265-290. Academic Press, Inc. New York.

Keddy, P.A. \& ShIPley, P. 1989. Competitive hierarchies in herbaceous plant communities. Oikos 54:234-241.

Kıra, T., Ogava, H. \& SaKazaKı, N. 1953. Intraspecific competition among higher plants. I. Competition-yielddensity interrelationship in regularly dispersed populatios. J. Inst. Polytech., Osaka City Univ., Ser. D $4: 1-16$.

LANG, R.W., Holmes, J.C., TAYlor, B.R. \& Waterson, H.A. 1975. The performance of barley variety mixtures. Expl. Husb. 28:53-59.

LoudA, S.M., Keeler, K.H. \& Holt, R.D. 1990. Herbivore influences on plant performance and competitive interactions. In: Grace,J.B. \& Tilman,D.(eds.). Perspectives on Plant Competition. p. 413-444. Academic Press, Inc. New York.

Makino, A., MaE, T. \& Ohira, K. 1984. Effect of nitrogen, phosphorus or potassium on the photosynthetic rate and ribulose-1,5-bisphoshate carboxylase content 
in rice leaves during expansion. Soil Sci. Pl. Nutr. 30:63-70.

Mather, K. \& Caligarı, P.D.S. 1981. Competitive interactions in Drosophila melanogaster. II. Measurement of competition. Heredity 46:239-254.

Mcdonald, B.A., Allard, R.W. \& Webster, R.K. 1988. Responses of two-, three-, and four-component barley mixtures to a variable pathogen population. Crop Sci. 28:447-452.

Mcgilchrist, C.A. \& Trenbath, B.R. 1971. A revised analysis of plant competition experiments. Biometrics 27:659-671.

Mead, R. \& Riley, J. 1981. A review of statistical ideas relevant to intercropping research. J. R. Statist. Soc. A 144,4:462-509.

Metivier, J.R. \& Dale, J.E. 1977. The utilization of endosperm reserves during early growth of barley cultivars and the effect of time of application of nitrogen. Ann. Bot. 41:715-728.

Mitchley, J. 1988. Control of relative abundance of perennials in ehalk grassland in southern England. II. Vertical canopy structure. J. Ecol. 76:341-350.

Mitchley, J. \& GrubB, P.J. 1986. The control of relative abundance of perennials in chalk grassland in southern England. I. Constancy of rank order and results of pot and field experiments on the role of interference. J. Ecol. 74:1139-1166.

MoOney, H.A. 1972. The carbon balance of plants. Ann. Rev. Ecol. Syst. 3:315-346.

Mooney, H.A. \& Gulmon, S.L. 1979. Environmental and evolutionary constraits on the photosynthetic characteristics of higher plants. In: O.T. Solbrig, S.Jain, G.B. Johnson and P.H. Raven (eds.). Topics in Plant Population Biology. Columbia University Press. New York.

Newman, E.I. 1973. Competition and diversity in herbaceous vegetation. Nature 244:310.

Nitzshe, W. \& Hesselbach, J. 1983. Sortenmischungen statt Viellien-Sorten. 1. Sommergerste (Hordeum vulgare L.). Z. Pfl.zuchtg. 90:68-74.

Pearce, S.C. \& Edmondson, R.N. 1984. Experimenting with intercrops. Biometrics 40: 231-237.

Pearce, S.C. \& Gilliver, B. 1978. The statistical analysis of data from intercropping experiments. J. Agric. Sci., Camb. 91:625-632.

Perby, H. \& Jensen, P. 1984. Net uptake and partitioning of nitrogen and potassium in cultivars of barley during ageing. Physiol. Pl. 61:559-565.

Pickett, S.T.A. \& Bazzaz, F.A. 1978. Organization of an assemblage of early successional species on a soil moisture gradient. Ecology 59:1248-1255.

Radosevitch, S.R. \& Roush, M.L. 1990. The role of competition in agriculture. In: Grace, J.B. \& Tilman, D. (eds.). Perspectives on Plant Competition. p. 341-363. Academic Press, Inc. New York.

Roush, M.L. \& Radosevitch, S.R. 1985. Relationship between growth and competitiveness of four annual weeds. J. Appl. Ecol. 22:895-905.

Roush, M.L. \& Radosevitch, S.R. 1987. A weed community model of germination, growth and competition of annual weed species. Abstr. Weed Sci. Soc. Am. 27:55. (Ref. Radosevitch, S.R. \& Roush, M.L. 1990)

SAlminen, M. 1945. Onko ohrakaura-sekaviljan viljeminen puollettavissa. Koetoim. ja Käyt. 2:6-7.

SANDFAER, J. 1970. An analysis of the competition between some barley varieties. Risö Rep. 230. Danish atomic energy commission. 114 p. Roskilde.

Shorter, R. \& Frey, K.J. 1979. Relative yields of mixtures and monocultures of oat genotypes. Crop Sci. 19:548-553.

Simmonds, N.W. 1962. Variability in crop plants, its use and conservation. Biol. Rev. 37:442-465.

SpItTERS, C.J.T. 1979. Competition and its consequences for selection in barley breeding. Agric. Res. Rep. 893:1-268.

SpItTERS, C.J.T. 1983. An alternative approach to the analysis of mixed cropping experiments. I. Estimation of competition effects. Neth. J. Agric. Sci. 31:1-11.

SPITTERS, C.J.T. 1984. Effects of intergenotypic competition on selection. Proceed. 10th Congr. Eur. Assoc. Res. Pl. Breed. EUCARPIA. p. 13-27. Wageningen.

Spitters, C.J.T. \& Berg, J.P. van den. 1982. Competition between crop and weeds: A system approach. In: Holzner, W. \& Numata, N.(eds.). Biology and Ecology of Weeds. p.137-148. Hague.

Spitters, C.J.T. \& Kramer, TH. 1986. Differences between spring wheat cultivars in early growth. Euphytica 35: 273-292.

Steel, R.G.D. \& Torrie, J.H. 1980. Principles and Procedures of Statistics. A Biometrical Approach. 2nd Edition. 633 p. McGraw-Hill Kogakusha, Ltd. Tokyo.

SYME, J.R. \& BREMner, B.M. 1968. Growth and yield of pure and mixed crops of oats and barley. J. Appl. Ecol. 5:659-674.

TAYLOR, B.R. 1978. Studies on a barley-oats mixture. J. Agric. Sci., Camb. 91:587-591.

THORnLEY, J.H. 1972. A balanced quantitative model for root-shoot ratios in vegetative plants. Ann. Bot. 36:431-441.

Tilman, D. 1982. Resource Competition and Community Structure. 296 p. Princeton University Press. Princeton.

Tilman, D. 1988. Plant Strategies and the Dynamics and Structure of Plant Communities. 360 p. Princeton University Press. Princeton.

TILMAN, D. 1990. Mechanism of plant competition for nutrients: The elements of a predictive theory of competition. In: Grace, J.B. \& Tilman, D. (eds.). Perspectives on Plant Competition. p. 117-141. Academic Press, Inc. New York.

Trenbath, B.R. 1974. Biomass productivity of mixtures. Adv. Agron. 26:177-210.

Trenbath, B.R. 1976. Plant interactions in mixed crop communities. In: R.I. Papendick et al. (eds). Multiple Cropping. Am. Soc. Agron. Spec. Publ. 27:126-169. 
Madison.

Trenbath, B.R. 1978. Models and interpretation of mixture experiments. In Wilson, J.R. (ed.). Plant Relations in Pasture. CSIRO. p.145-162. Melbourne.

Trenbath, B.R. 1983. The dynamic properties of mixed crops. Intern. Conf. Frontiers Res. Agric. September 27-October 1, 1982. Publ. Ind. Statist. Ins. Calcutta, India. $22 \mathrm{p}$.

Turkington, R. 1989. The growth, distribution and neighbour relationship of Trifolium repens in a permanent pasture. VI. Conditioning effects by neighbours. J. Ecol. 77:734-746.

VAlentine, J. 1982. Variation in monoculture and in mixture for grain yield and other characters in spring barley. Ann. Appl. Biol. 101:127-141.

VANDERMEeR, J. 1989. The Ecology of Intercropping. 237 p. Cambridge University Press. Cambridge.

Vermeulen, S.E.J.W. 1991. Yield analysis of a long term field trial with spring wheat, barley and oats in Finland. (Manuscript submitted to Fert. Res.).

WEINER, J. 1986. How competition for light and nutrients affects size variability in Ipomea tricolor populations. Ecology 67:1425-1427.

WeINER, J. 1990. Asymmetric competition in plant populations. Trends Ecol. Evol. 5:360-364.

WEINER,J. \& THOMAS, S.C. 1986. Size variability and competition in plant monocultures. Oikos 47:211-222.

WhItTAKER, J.B. 1979. Invertebrate grazing, competition and plant dynamics. In: Anderson, R.M., Turner, B.D.
\& Taylor, L.R.(eds.). Population Dynamics. p. 207-222. Blackwell, Oxford.

WILleY, R.W. 1979. Intercropping - Its importance and research needs. Part 1. Competition and yield advantages. Field Crop Abstr. 32:1-10.

WILLEY, R.W. 1985. Evaluation and presentation of intercropping advantages. Exp. Agric. 21:119-133.

Willey, R.W. \& Heath, S.B. 1969. The quantitative relationship between populations and crop yield. Adv. Agron. 21:281-321.

Willey,R.W. \& RAO, M.R. 1980. A competitive ratio for quantifying competition between intercrops. Exp. Agric. 16:117-125.

WILson, J.B. 1988. The effect of initial advantage on the course of plant competition. Oikos 51:19-24.

Wiт, C.T.de. 1960. On competition. Versl. Landbouwk. Onderz. 66.8:1-88.

WIT, C.T. de \& BERG, J.P. van den. 1965. Competition between herbage plants. Neth. J. Agric. Sci. 13:212-221.

WOLfE, M.S. 1985. The current status and prospects of multiline cultivars and variety mixtures for disease resistance. Ann. Rev. Phytopath. 23:251-73.

Wolfe, M.S. \& Barrett, J.A. 1979. Disease in crops: Controlling the evolution of plant pathogens. J. R. Soc. Arts 127:321-333.

WRIGHT, A.J. 1981. The analysis of yield-density relationship in binary mixtures using inverse polynomials. J. Agric. Sci., Camb. 96:561-567.

\section{SELOSTUS}

\section{Kilpailu ja satoetu sekä ohran lajikeseoksissa että ohran ja kauran lajiseoksissa}

\author{
Kari Jokinen \\ Helsingin yliopisto, Kasvinviljelytieteen laitos, \\ Viikki, \\ 00710 Helsinki
}

Kenttäkokein tutkittiin ohran lajikeseoksissa ja ohran ja kauran lajiseoksissa tapahtuvaa kilpailua ja seosten sadontuottoa. Kokeet perustuivat korvaussarjakoemalliin. Seosten komponentit olivat virallisia lajikkeita.

Sekä de Wit-malli että regressioanalyysiin perustuva kilpailumalli osoittivat komponenttien valtaavuussuhteet samansuuntaisesti. Regressioanalyysi kuvasi kilpailua erityisesti tiheissä kasvustoissa.

Lajikkeen kilpailukyky ei ollut yksiselitteisesti riippuvainen lajikkeen yhdestă ominaisuudesta kuten esimerkiksi alkukehityksen nopeudesta, aikaisuudesta, korren pituudesta tai puhdaskasvustosadon mäărästả. Ohralajik- keista Arran nopea alkukehitys ja aikaisuus oli hyvă yhdistelmä kilpailukyvyn kannalta lajikkeen ollessa aina vallitseva. Arran vallitsevuus oli riippumaton seoksen komponenttien lukumäärästà, seoksen kylvötiheydestä, typpilannoituksen määrästä ja kasvukaudesta. Muiden lajikkeiden kilpailukyky vaihteli ympäristöstä toiseen komponenttien kilpailusuhteiden ollessa vaihtelevia. Yleensă vallitsevan lajikkeen vallitsevuus lisäăntyi kasvuston typpilannoituksen lisääntyessä, kun kasvuston kylvötiheys oli suuri. Kilpailu vaikutti kaikkiin satokomponentteihin kilpailuvaikutuksen kohdistuessa văhiten jyvăn painoon. Lajikeseosten jyvăsato ei ollut tilastollisesti merkit- 
sevăsti suurempi kuin eniten puhdaskasvustona tuottaneen komponentin jyvăsato. Lajikeseosten suhteellinen kokonaissato oli suurempi harvassa $($ RYT $>1)$ kuin kasvutiheyden suhteen optimaalisessa kasvustossa ( $R Y T=1)$. Lajikeseosten suhteellinen kokonaissato oli suurempi kasvustossa, jonka typpilannoituksen mäărä ei ollut optimaalinen. Kolmena peräkkäisenä kasvukautena toistettujen lajikeseosten suhteellinen kokonaissato oli lăhellă yhtă. Siten tulokset osoittivat, että hyvin sopeutuneet ohralajikkeet kilpailevat samoista kasvutekijöistä ja seosten satoetu jyväsadon mäărän suhteen on marginaalinen.

Ohran ja kauran lajiseosten jyvăsato oli joissakin tapauksissa tilastollisesti merkitsevästi suurempi kuin enit- en puhdaskasvustona tuottaneen komponentin jyväsato. Lajiseosten suhteellinen kokonaissato oli yleensă yhtă suuri tai suurempi kuin yksi jälkimmäisen tapauksen osoittaessa, että seokset saattavat hyödyntăä kasvutekijöită paremmin kuin vastaavat puhdaskasvustot ja seosten käyttő saattaa olla perusteltua.

Lajiseoksen valkuaissato ei poikennut tilastollisesti merkitsevăsti eniten puhdaskasvustona tuottaneen komponentin sadosta. Suhteellinen kokonaissato valkuaissadon suhteen oli tavallisesti suurempi kuin yksi. Seokset eivăt olleet yksiselitteisesti jyväsadon määrän suhteen vakaampia sadontuottajia kuin puhdaskasvustot vaihtelukertoimella mitattuna. 